\title{
Preliminary analysis of social responsibility inside Chilean universities
}

\author{
Erwin Eduardo Navarrete ${ }^{1,2 \star}$, Juan Pedro Sepúlveda Rojas ${ }^{2,3}$ and \\ Jorge Ignacio Alvial Pantoja ${ }^{4}$ \\ ${ }^{1}$ Facultad de Arquitectura, Diseño y Construcción, Escuela de Construcción Civil, Universidad Mayor, \\ Campus Av. Alemania, Av. Alemania 0281, Temuco, Chile. \\ ${ }^{2}$ Facultad de Ciencias Físicas y Matemáticas, Escuela de Ingeniería Civil Industrial, Universidad Central de Chile, \\ Avda. Santa Isabel 1186, Santiago, Chile. \\ ${ }^{3}$ Facultad de Ingeniería, Universidad Diego Portales, Vergara 432, Santiago, Chile. \\ ${ }^{4}$ Instituto de Obras Civiles, Facultad de Ciencias de la Ingeniería, Universidad Austral de Chile, General Lagos 2086, \\ Valdivia, Chile. \\ Accepted 13 March, 2012
}

\begin{abstract}
The article describes initiatives concerning social responsibility carried out by Chilean universities and the way these initiatives are incorporated into their strategic processes. The main goal is to determine opportunities and limitations wherein a university could take advantages of its role as social developer to impel sustainable development in the community it is inserted in. In this context, to face the huge competition existing in the Chilean higher education system, education institution have had to discover the role played by social responsibility as a powerful source of competitive advantage allowing them to keep a determined viability and to generate value in the "market". This work is the result of an exploratory research built on the basis of literature and experience, through observation and participation in the Chilean system of higher education. The present document is limited regarding experimental data. Future research must examine exploration factors and correlation among them for experimental research. Results show competitive advantages for universities by maximizing their contributions to social causes, thus expressing greater commitments towards the community, which yields by providing better visibility throughout time.
\end{abstract}

Key words: Social responsibility, ethics, competitive advantages, higher education, Chile.

\section{INTRODUCTION}

Results of an exploratory investigation based on literature and experiences, through observation and participation in the Chilean system for higher education are presented in this work. This document pretends to describe initiatives regarding social responsibilities carried out by Chilean Universities and the way these initiatives become an integral part of their strategies. The main goal is to determine opportunities and limitations wherein a university could take advantage of its role as social developer to

\footnotetext{
${ }^{*}$ Corresponding author. E-mail: erwineconomy@hotmail.com .
} Tel: $+(56-45) 206365$. foster and impel a sustainable development. Contribution is oriented to delivering information to understand the way Chilean universities can make a difference inside higher education industry, hence generating a competitive position through a combination of excellence quality education and social responsibility with the aim of amalgamating these concept practices into their actions. Furthermore, a simple frame to classify socially responsible universities is proposed in this research since they are agents keeping an interactive dialog with society. Thus, this study first gave a brief presentation of the concept of managerial social responsibility, its principles and a conceptual revision of university social responsibility to set up certain parameters and differences 
among them, to provide a unique understanding and establish differences based on its application scope. Afterwards, an examination of literature presenting relationships between social responsibility and university is provided. Lastly, this research describes how a university can take competitive advantages so as to maximize its contribution to social causes, thus obtaining greater visibility and permanence in the long term, characterized by strong orientation and commitment towards the community. The document concludes with a discussion about social responsibility implications in higher education.

\section{LITERATURE EXAMINATION}

To improve understanding the meaning of university social responsibility (USR), and to avoid misunderstandings in conceptual terms and application, some definitions and principles forming part of the corporations or managerial social responsibility (MSR) will be mentioned first. Afterwards, antecedents to introduce and to better understand how this concept converges in the higher education scope, specifically in Chilean universities, will be provided.

\section{Managerial social responsibility}

Since the second half of the twentieth century, there has been much debate as to how managerial social responsibility (MSR) has been defined and put into practice. Both in the academic and business world there is much uncertainty regarding how MSR must be faced and what criteria should be used to carry out a theoretical approximation of the social responsibility meaning for organizations. Adding to the previously exposed studies, the fast evolution experimented by this field of studies translated into a significant growth, witnessed nowadays by a huge number of approaches, theories and terminology regarding MSR (Shocker and Sethi, 1973; Sethi, 1975; Carroll, 1979; Lozano, 1999; Marrewijk, 2003; Garriga and Melé, 2004; Valor and Hurtado, 2009). This is demonstrated in the research carried out by Dahlsrud (2008), where he identifies 37 definitions in the business area.

Consequently, there is neither a clear conceptual frame nor a generally accepted structure of the term since present literature on the topic is inconsistent and strongly fragmented. As a result of this strong proliferation of theories and meanings, which are, according to Van a Marrewijk (2003), strongly biased towards specific interests, the development and implementation of this concept is avoided.

Furthermore, considering the low number of empirical experience, understanding its meaning and reach becomes more difficult. Under this scenario, a literature examination was done, so as to deepen into the concept; the best known and accepted definitions, from the scientific perspective, were reviewed.

\section{What is social responsibility?}

According to the World Business Council for a Sustainable Development (WBCSD, 1999), MSR is "the compromise assumed by the corporation to contribute to sustainable economical development by means of collaboration with their employees and their families, the local community and the society, with the object of improving life quality". Vallaeys (2006a) indicates that for Britons social responsibility is considered as a competitiveness and profitability tool; for Germans, this concept is centered in the community and corporate citizenship; whereas, for example French people mistrust it since they consider it as a strategy for public opinion manipulation. In USA, it is a matter of image and good reputation of companies. And for us, in Latin America, social responsibility is understood as a charity activity, as a part of philanthropy. Vallaeys (2006b) himself coined his own definition of SR as a different way to understand normal ethics, based on a dialectic ethics starting from a holistic and systemic approach of the immediate surroundings.

Another widely used definition is ISO 26000; SR corresponds with the responsibility of an organization due to the impact produced by their decisions and activities in the society and environment through a transparent and ethical behavior compatible with sustainable development and society welfare, considering expectancies of interest groups (especially expectancies from those vulnerable groups and for future generations) and accomplishing international norms and integrated throughout the whole organization.

Finally, the European Communities Commission (2001) defines it as "The voluntary integration, by corporations, of social and environmental concerns into their commercial operations and relationships with the surroundings. To be socially responsible does not only mean to plentifully accomplish juridical obligations; it means to go beyond what their duties and obligations are, investing more in human capital, the environment and relationships with interlocutors".

The lack of consensus observed in the revision of literature concerning this topic forces us to propose some MSR central elements; this with the purpose of somehow orientating and establishing minimal criteria to meditate about the importance of this concept for XXI Century organizations (Figure 1).

\section{Principles on which managerial social responsibility is based}

The ten principles of the United Nations Organization 


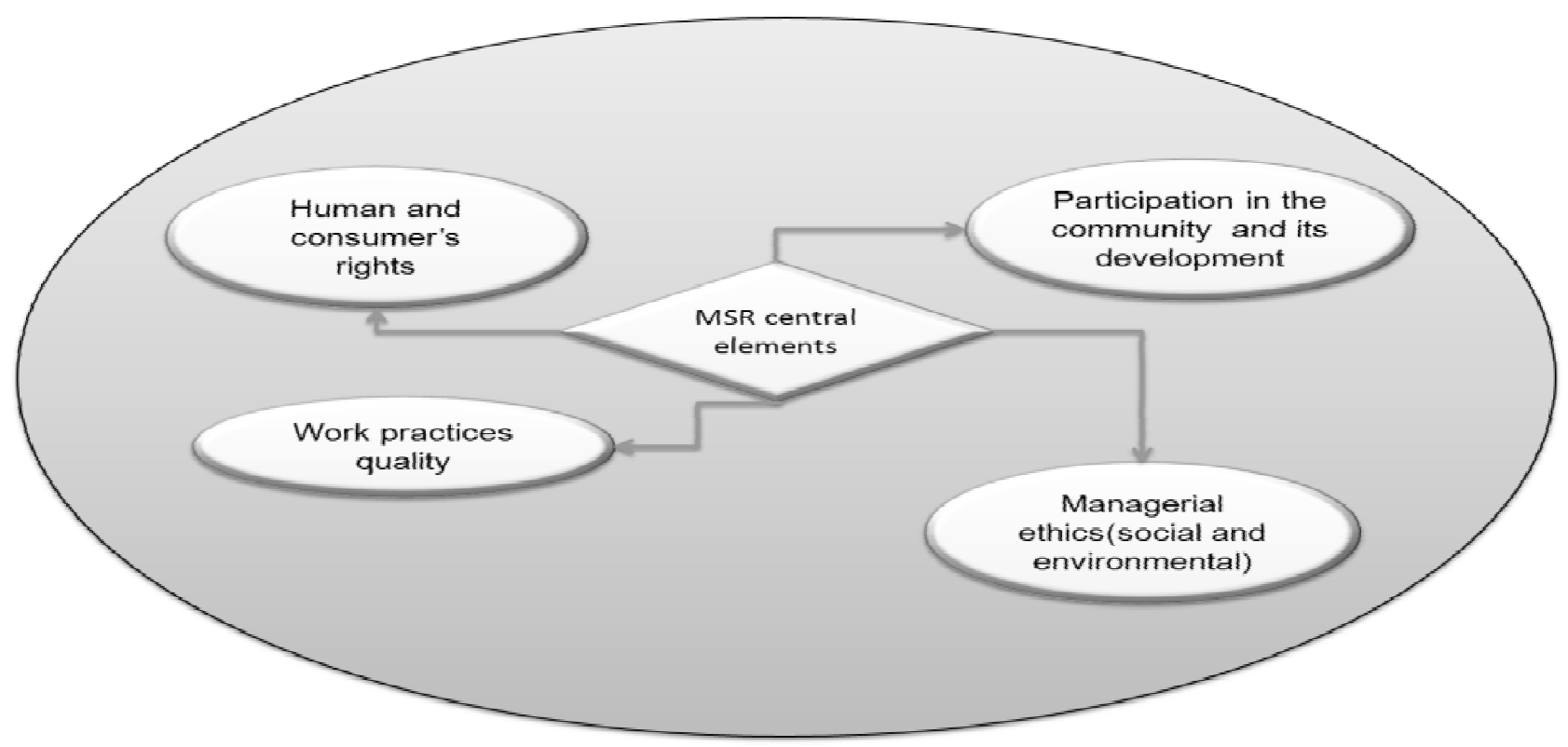

Figure 1. Central elements of MSR.

(UNO), the World Pact, regarding MSR are given as follows:

1. Corporations must support and respect protection of fundamental human rights, worldwide recognized, inside their influence scope.

2. Corporations must make sure their companies are not accomplices in human rights violations.

3. Corporations must support freedom for workers unions creation and the effective acknowledgement of the right to collective bargaining.

4. Corporations must support the elimination of any form of forced labor or made under coercion.

5. Corporations must support the eradication of children work.

6. Corporations must support abolition of discrimination practices in Jobs.

7. Corporations must keep a preventive approach favoring the environment.

8. Corporations must foster initiatives promoting higher environmental responsibilities.

9. Corporations must favor the development and diffusion of those technologies friendly to the environment.

10. Corporations must work against any form of corruption, included extortion and bribery.

Crowther and Aras (2008) in their book "Social Responsibility inside the Corporation" insisted that the central principle of SR is the social contract among all actors of society; it is an essential requirement for civil society. According to them, SR is not only limited to the present members of a society, it should also be extended for its future members. That is to say, organizations are not working in vacuo, and apparently their work will affect their external environment.

\section{Social responsibility inside the university}

According to what has been exposed, the concept of social responsibility is mainly linked with the business world, where to include community interests in the normal process of decision taking is emphasized so as to improve organizational practices and contribute to enhance corporations reputation in front of public opinion.

Though with time, SR has moved to other areas, such as public institutions and higher education. Under this scenario, Universities are making their best efforts to implement this concept. Similar to those difficulties found when trying to get a consensus about SR delimitations inside a corporation, building a conceptual base in education will also be a challenge due to the little research about the concept of USR.

Some studies are centered on the responsibility of the academic leaders who must guarantee opportunities to educate the most responsible students (Immerwahr, 1999; Gibbons, 2005). Others consider social responsibility as part of the university mission (Badat, 2009; Fonlon, 2009; Goosen, 2009). More attention is given to the relationship between universities and the different stakeholders categories (Stevens and Bagby, 2001; Benneworth and Jongbloed, 2009), emphasizing stakeholders importance in knowledge transfer or in the way the administration answers the interests of the university community.

Responsibility of higher education institutions towards society directly comes from its social mission, wherein the main functions of a University are established; those 
covering areas such as teaching, research, relationship with the environment and university management. Consequently, higher education is considered an instrument of national competitiveness allowing the countries for a better integration into the global economy (Levin, 2006).

In this direction, efforts of universities are centered in the creation and implementation of innovative academic programs, enhancing quality through offering their methodological characteristics, ending in the conditioning of students for their future professional development (Atakan and Eker, 2007); including the huge responsibility of transforming students into ethically responsible authorities able to take decisions affecting the common wealth of people.

Regarding research, universities are responsible for generating relevant and significant knowledge; coherent with the future development of society. The University is definitively the institution responsible for posing ideas and profusely reflecting to be able to propose options leading to the solution of the main problems humanity have to face during its existence.

Universities, by means of teaching and research must develop a responsible behavior able to give answers to human life needs and to sustainable development. Therefore, the role of these education institutions is to generate and spread knowledge so that this knowledge can be carried out through active participation in the community life. The role of higher education must be related with adopting a position effectively facing regional, national, continental and worldwide economical and social challenges (Badat, 2009).

Accordingly, universities must promote an authentic responsibility culture inside their organizations and must develop social actions leading to communication and interaction with the interested parties (Goossen, 2009). These study organizations must continue as sacred places, where spaces for intellectual birth are forged wrapped in skills and enthusiasm to altruistically assume and promote social responsibility (Fonlon, 2009).

Social service implies alliances with the communities to support their objectives and values. Contribution to society development seems to be the most important role; a holistic approach of the combination among teaching, investigation and social services in a way that allows for the sustainable development and enhancement of people's life quality. To educate persons, to create advanced knowledge offering solutions to the most complex problems society faces today is the role essence universities play in society.

\section{What is university social responsibility?}

Considering all aspects defining university role in societies, it seems the concept of SR is inherent to their own character. Therefore, university SR is a policy of ethical performance of the university community (students, faculties and administrative staff) through a responsible management of education, cognitive work and the impact over environment; an interactive dialog with society for the promotion of human development (Reiser, 2008).

This can also serve as an ethical approach to develop a sense of civic citizenship, where socially responsible students, academics and faculties succeed in promoting socio-environmental, ecological, technical and economical participation for a sustainable development of the global and local community (Arnzten, 2008).

Like MSR, USR is not free from terminological confusions and from the lack of a clear delimitation in the university scope; hence we will check some of the most relevant definitions used in the academic and in the research areas, besides presenting certain characteristics supporting the concept actions.

Vallaeys (2006b) defines it as "a way to carry out an integral administration of the institution, in such a way that its impacts regarding all actors involved be socially managed", making clear that "this impact management must be ethically and intelligently done; understanding intelligent as a management seeking for revenues benefitting the organization".

On the other hand, the project "University Builds Country" (2007) describes USR as a "Capacity possessed by universities to put into practice a conglomerate of general and specific principles and values, through 4 processes considered as crucial by the Universities; they are, management, teaching, research and extension. Thus socially answering to the university community itself and the country it is inserted in".

Chomsky (2002) states that USR is "a liberating and subversive function allowing society to discriminate whether the present order, authority and dominance institutions are useful concerning fundamental human needs and rights".

From the previously stated definitions, we can build our own meaning and understanding about USR significance; understood as the capacity to diffuse and implement a series of principles and values, by means of key processes, such as management activities, teaching, research and extension to the community, to facilitate sustainability in its economical, social and environmental dimensions (Figure 2).

Once USR central elements have been exposed, higher education institutions have seen this concept as a powerful source for competitive advantage. Nonetheless, literature does not present any agreement regarding this issue; furthermore, information sources are scarce to permit the analysis of what extent universities advocate to SR initiatives (Nicolescu, 2007).

The highly competitive scenario of Chilean Higher Education Industry has made universities start implementing clear initiatives of SR in their strategic planning with the purpose of improving their position in the market in aspects as image, reputation, trade mark strengthening and enhancement of institutional value.

These education institutions must make a difference 


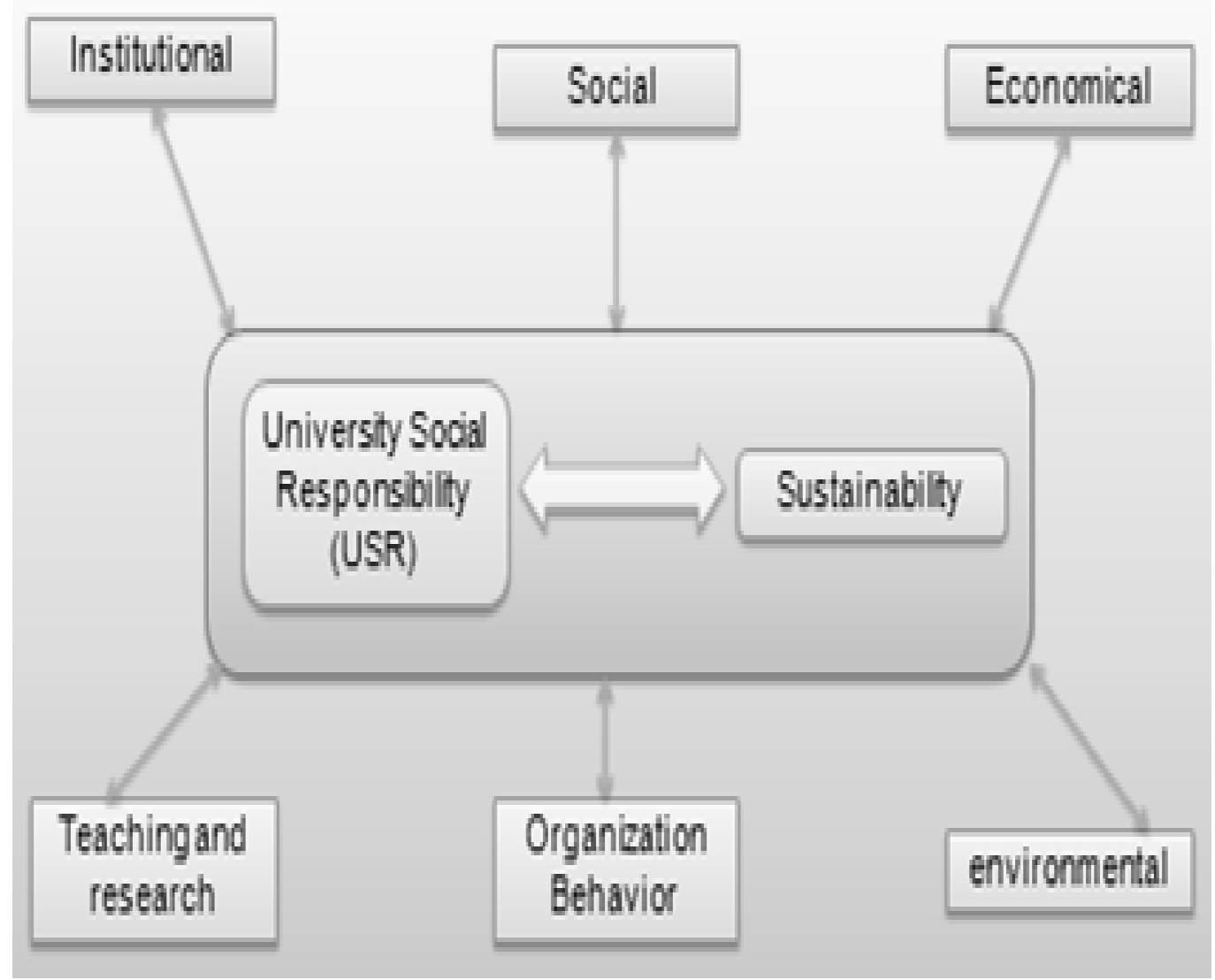

Figure 2. USR central elements.

and establish a competitive position through a combination of high quality education and SR. Figure 3 shows the four dimensions covered by social responsibility in the University: Organization's environment, educational, social and cognitive impact (Militaru and lonescu, 2008).

Twenty First Century organizations have come to understand that they are inserted inside a system in which to satisfy necessities by means of elaboration or commercialization of goods and services aimed at financial or economic revenue appears as not enough.

Nowadays, executives or owners of these institutions must pay special attention to demands and expectancies from the varied public included in that society. This is applied to any type of organizations, including our universities. All of them must respond to the community, that is to say, respond to those social needs expressed in connection with environment, security, health, fair labor conditions, and first and foremost, it has to be done under an ethics expressing the fundamental values of an organization. Which have to be put into practice -in the case of education institutions- by its administrative staff, academics and students.

Universities decisions and activities have always a direct effect over the natural environment, regardless of where they are. These impacts may be linked with the indiscriminate use of water and energy and/or contaminants and wastes generation. To reduce those environmental impacts, universities must increase their students' awareness concerning the environment, and actively contribute to their improvement (Porter and Kramer, 2006). These changes arise when students are educated in values and in the comprehension of the society they are inserted in. To achieve this, the university community could openly participate in projects useful for the community, thus acquiring a voluntary compromise and an interdisciplinary work to contribute to society. Social impact is generated when the university opens its gates to welcome students coming from the most vulnerable and disfavored areas of the population; that is when the university assumes the responsibility and challenge of keeping this type of students inside the education system, accompanied by good academic performance, or involved in projects jointly developed with different other social agents.

Concerning cognitive impact, this is built when research tasks are open to sustainable human development, when researches cover issues such as poverty, human gender and disability; when learning is shared with other community actors, and besides when this knowledge accomplishes pertinence and quality standards imposed by the university. Those impacts lead us to formulate the following hypothesis: 


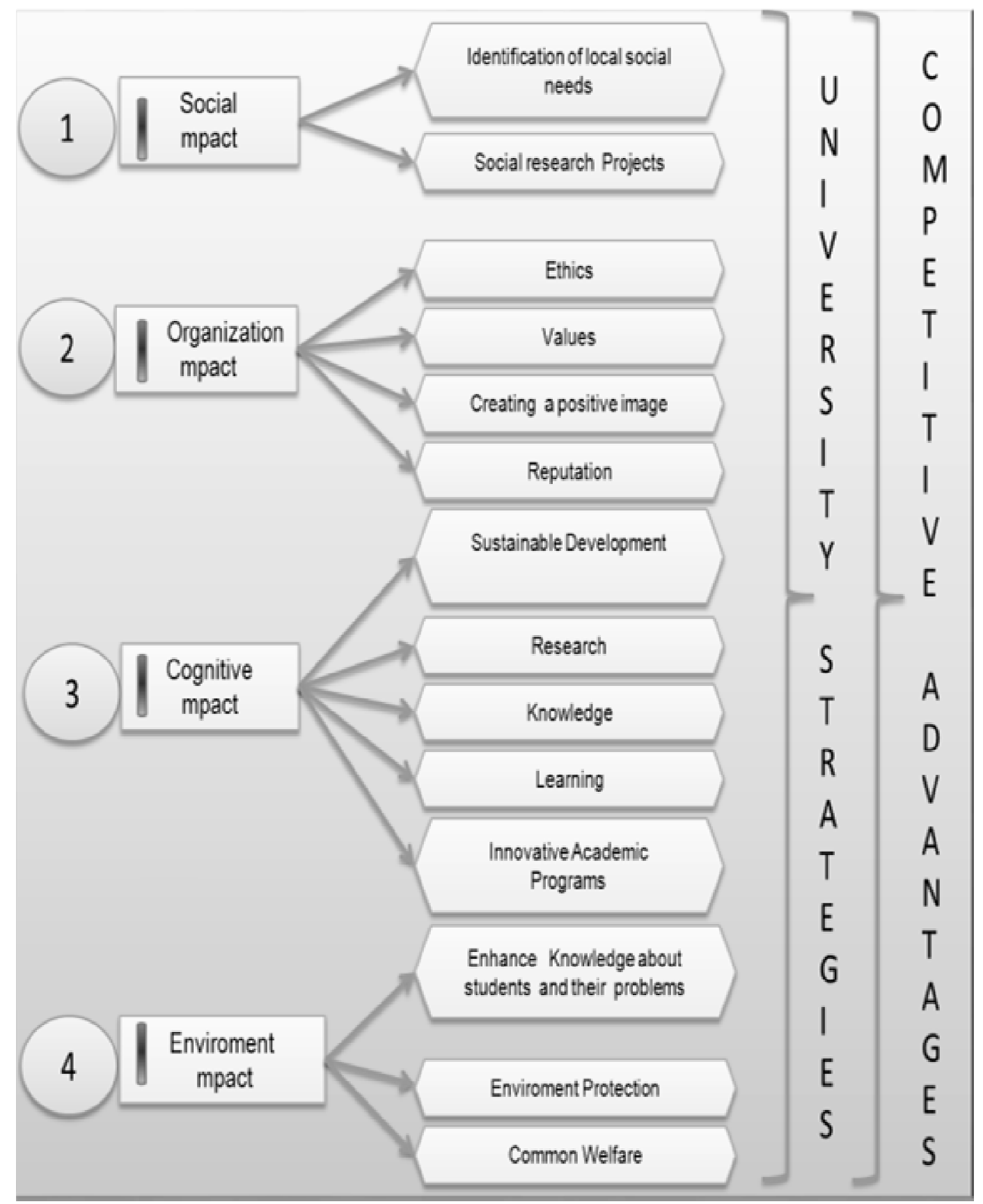

Figure 3. The 4 "dimensions" of University social responsibility.

"Knowledge generated by universities has a positive impact on teaching, research and social needs integration"

USR has an evident cost translated into money, personal cost, time and expertise. Although, through an efficient social responsibility program, universities may get important advantages, such as image improvement, maintenance and motivation of their internal clients as, for example, their employees (Porter and Kramer, 2002).
SR in education appears as "a dynamic platform to teach a series of present issues of society. Flexibility and quality are essential criteria for an effective transition from the degree of bachelor towards the degree of master. In this case, students' social protection through financial aid programs must continue, and principally must be in agreement with our country social reality. Most Chilean universities are not using transparency and credibility instruments in their SR initiatives. Based on these arguments the following hypothesis is stated: 
"The stronger the bond between a university strategy and a social cause, the superior the impact and benefit on the society"

Hence, it could be stated that universities are the main actors to produce those changes, though Chilean nexus universities are not capable of, successfully, facing these challenges. There is much criticism by students regarding quality of provided education services, and funding options or plans.

\section{Methodological aspects}

It is an exploratory study, based on qualitative research and a descriptive design whose aim is to achieve a deeper comprehension of how Chilean universities integrate their SR initiatives inside their strategies to get competitive advantage in the "market" of Chilean higher education.

The basic justification for this research arises from the fact that University Social Responsibility helps these institutions to improve their image, strengthen their trademarks and enhance their institutional and ethical value in front of the community. Thorough interviews to academics, students and staff in charge of social responsibility projects were carried out with the aim of obtaining primary information.

Different instruments were used for data collection: questionnaires, interviews with key actors inside the universities, public documents analyses and analyses of internal documents unknown by the public opinion. Those interviewed were 5 university administrators, 8 members of the academic staff, and 18 students from Construction School of Universidad Mayor, and students of Industrial Civil Engineering from the Faculty of Mathematics and Physical Sciences of Universidad Central de Chile.

The previously mentioned instruments were applied by the author and a students' team. Interviews also covered the identification of social responsibility initiatives of universities, their application and their results concerning benefits for the local community, for the university and for the departments and students as well.

\section{RESULTS}

In Chile, the most generalized motivations for companies to give help through donations are causes $(70 \%)$ and humanitarians (including help for the child and/or the poor). This could explain why areas such as environment protection and civic education are not found within those donation areas favored by the Chilean impresario.

A remarkable academician indicated the following when interviewed: "A University cannot work as an institution isolated from its social background and must get the compromise to re-invent society. This must be integrated with the community to create a synergy so as to contribute to social development and the building a knowledge-based society".

On the other hand, an important element unveiled by the interviews results is that Chilean students and the academic staff do not perceive universities as socially responsible. Nevertheless, those interviews done to management staff reveal that a university may contribute by teaching ethics to its students. When trying to find out about reasons of universities to participate in social responsibility actions, results showed that a $35 \%$ of those interviewed believes these institutions act forced by exogenous pressure, and 3 out of 10 think this chore is assumed to enhance prestige or reputation. Equally, surprising is the fact that a $15 \%$ thinks universities assume this imperative as a fashion (Table 1).

When talking with students, many of them indicate being disenchanted after entering into the higher education system, either because most academic alternatives are mainly concentrated on classical and theoretical activities in detriment of cultivating practical abilities and knowledge within the formal curriculum.

To the question "To what extent do you think university graduated students are familiar with SR concept and practice as a result of formal education programs offered by your Faculty?" A large number of academics and students of Chilean universities involved in this work have answered that the issued is only slightly mentioned and there is no formal discipline centered on social responsibility.

Complementarily, the fact that only $30 \%$ of interviewed people declared themselves as familiarized with SR concept. An overwhelming $60 \%$ declared having little knowledge about Social responsibility. An assistant teacher from Construction School of Universidad Mayor answered as follows "The topic is marginally mentioned and there is no formal discipline centered on SR".

Universities described in this research implement a competence based education; a formation that has not been capable of coping with the rhythm of the complex and dynamic contexts of the new organization background. Not only are study programs insufficient from the interdisciplinary perspective, but they also reflect a scarce international orientation. Concerning this issue, courses explicitly referring to social responsibility are being recently included in curricular programs in our country.

The purpose of these SR courses is to familiarize students and academics with those basic elements of SR. The advantages of these courses lie upon the fact that they allow students to develop a series of basic skills in the field of SR and to generate a logical thinking and awareness in this topic.

\section{Referential frame for social responsibility}

A referential frame to classify universities social responsibility may be defined as the cluster of institutional impacts produced by those actions upon society and environment. This classification is presented on Table 2.

\section{Conclusion}

Integration and association of social responsibility with 
Table 1. Reasons for Social responsibility participation.

\begin{tabular}{lc}
\hline Items & Results (\%) \\
\hline Universities are forced by external pressures & 35 \\
University reputation enhancement & 30 \\
It is a fashion & 15 \\
To get a competitive advantage & 5 \\
Attract and keep good students & 3 \\
Attract and keep good academic staff & 8 \\
To reduce operation costs. & 2 \\
\hline
\end{tabular}

Table 2. Reference frame to classify Universities social responsibility.

\begin{tabular}{ll}
\hline Primary criterion & Secondary criterion \\
\hline Educational & $\begin{array}{l}\text { Teaching quality and research. } \\
\text { Ethical/moral principles. }\end{array}$ \\
Organizational & $\begin{array}{l}\text { Reputation. } \\
\text { Values. } \\
\text { Receiving poor and disabled students. } \\
\text { Health, security and working fair conditions. }\end{array}$ \\
Environmental & $\begin{array}{l}\text { Reducing contamination, wastes, Carbon Emissions or Energy. } \\
\text { Social }\end{array}$ \\
Long-term compromise with the community. \\
Improving graduate students' performance to compete in the job market. \\
Tolerance and Respect for biodiversity of individuals. \\
Sognitive
\end{tabular}

the Industry and study plans of the diverse careers composing the academic offer in Chile will mean a transformation of education institutions attitude, thus producing social changes by acting as engaged and socially responsible actors inside a community. University must assume leadership in the transformation of Chilean society and must assume the hard task of beginning these changes so that they become visible and responsible, involving the different agents composing a determined community.

It is imperative that efforts be service based, where not only students but also the different interest public forming part of our society becomes its core as well. Our results show that universities may get competitive advantages if they maximize their contribution to social causes and get a superior visibility throughout time, accompanied by a strong compromise towards the community. Another conclusion of this study is that Chilean Universities are more centered in the internal dimension of MSR; most of them both concentrate their social responsibility actions and address them to their employees and their families. However, some companies increase their collaboration and support to high-schools with the aim of selecting their future employees; examples are Cisco, SAP and Microsoft.

The present document is limited concerning experimental data. Future research must examine exploration factors and the correlation among them through experimental investigation.

\section{REFERENCES}

Arnzten AAB (2008). From Corporate Responsibility (CSR) to University Social Responsibility (USR)" the influence of information communication Technology on University Corporate Responsibility, available

[http//www.usralliance.org/resources/Aurilla_Presentation_Sessions6. pdf], referred on 23 October 2009.

Atakan MGS, Eker T (2007). "Corporate identity of a socially responsible university: A case from the Turkish higher education sector", J. Bus. Ethics 76(1):55-68. 
Badat S (2009). "The role of higher education in society: valuing higher education", HERS-SA Academy, University of Cape Town, Graduate School of Business, Cap Town, available at [http:/eprints.ru.ac.za/1502/], referred on 22 October.

Benneworth P, Jongbloed BWA (2009). "Who matters to universities? A stakeholder perpective on humanities, arts and social sciencies valorization", Higher Education, №DOI 10.1007/s10734-009-9265-2.

Carroll A (1979). A three dimensional conceptual model of corporate performance. Acad. Manag. Rev. 4(4): 497-505.

Commission of the European Communities (2001). Promoting a European Framework for Corporate Social Responsibilities, COM 366 final, Brussels.

Crowther D, Aras M (2008).Corporate Social Responsibility. Copenhagen: Ventus Publishing.

Chomsky N (2002). The limits of globalization. Barcelona: Ariel.

Dahlsrud A (2008). How corporate social responsibility is defined: an analysis of 37 definitions. Corp. Soc. Responsib. Environ. Manag. 15(1):1-13.

Fonlon BN (2009). Genuine Intelletuals. Academic and Social Responsibilities of Universities in Africa, Langaa RPCIG.

Garriga E, Melé D (2004). Corporate Social Responsibility Theories: Mapping the Territory. J. Bus. Ethics 53 (1-2):51-71.

Gibbons M (2005). "Choice and Responsibility: Innovations in a New Context, Higher Education Management and Policy". J. Program. Inst. Manag. Higher Edu. 17(1):9-23.

Goosen R (2009). "Universities and Corporate Social Responsibility: A competitive Advantage?", Available at [http://www.avantage.com/content/universities-and-corporate-socialresponsibility-competitive-advantage], referred on 11 December.

Immerwahr J (1999). "Taking Resposibility Leader" Expectations of Higher Education", The National Center for Public Policy and Higher Education, available at http://www.highereducation.org/responsibility.shtml], referred on 11 December 2009. ISO26000, available at [http://www.iso.org/iso/iso_catalogue/management_and_leadership_s tandards/social_responsibility/sr_iso26000_overview.htm].

Levin R (2006). "Universities Branch Out: From their student bodies to their research practices, universities are becoming more global", Newsweek International, available at [http://www.law.yale.edu/documents/pdf/Public_Affairs/PresidentLevi nArticle.pdf], referred on 21 November 2009 pp.21-28.

Lozano J (1999). Ethics and business. Madrid 2009. Corporate citizen as a responsible and sustainable.Madrid: Trotta. The public company as a responsible and sustainable. Madrid: Trotta.

Marrewijk M (2003). Concepts and definitions of CSR and corporate sustainability: Between agency and communion. J. Bus. Ethics 44(2/3):95-105.

Militaru GH, Ionescu S (2008). "The corporate social responsibility and the supply chain: an empirical investigation", Proceeding of the 19th International DAAAM Symposium, 22-25th October, Trnava, Slovakia.
Nicolescu C (2007). "Business and Economics Graduates in Romania: Socially responsible or Socially Alienated?", International Policy Fellowships, Available at [http://www.soros.org/inistives].

United Nations Organization (ONU). The Global Compact [www.google.co.ve]

Porter M, Kramer M (2002). "The Competitive Advantage of Corporate Philanthropy", Harv. Bus. Rev. 12:57-68.

Porter M, Kramer M (2006). "Strategy and Society: The link between Competitive Advantage and Corporate social responsibility", Harv. Bus. Rev., 12: 78-92.

Reiser J (2008). University Social Responsibility definition, available at [http://www.usralliance.org/resources/Aurilla_Presentation_Session6. pdf.], retrived on 14 October 2009.

Sethi S (1975). Dimensions of Corporate Social Performance: An analytical framework. Calif. Manag. Rev. 17(3):58-64.

Socker A, Sethi S (1973). An approach to incorporating societal preferences in developing corporate action strategies. Calif. Manag. Rev. 15(4):97-105.

Stevens JM, Bagby JW (2001). "Knowledge Transfer from Universities to Business: Returns for all Stakeholders?" Organization 8(2):259268.

Build Country University (2007). Chile, Available at [www.construyepais.cl].

Vallaeys F (2006a). "A brief theoretical framework for university social responsibility", on CD: University Social Responsibility, Ethics and University Network for Social Development (RED), Inter-American Initiative on Social Capital, Ethics and Development Bank. Available at [http://www.udlap.mx/rsu].

Vallaeys F (2006b). "The hidden ethos of the University", on CD: University Social Responsibility, Ethics and University Network for Social Development (RED), Inter-American Initiative on Social Capital, Ethics and Development Bank. Available at [http:// www.udlap. $\mathrm{mx} / \mathrm{rsu}]$.

Valor C, Hurtado I (2009). Spanish companies and corporate social responsibility. The contribution to the Millennium Development Goals. Madrid: Cataract.

World Business Council for Sustainable Development (1999). Corporate Social Responsibility: Meeting Changing Expectations. World Business Council for Sustainable Development: Geneva. 